\title{
Comparison of two calculation methods for designing the solar electric power system for small islands
}

\author{
Angga Romana $^{I}$, Eko Adhi Setiawan ${ }^{* 1,2}$, and Kurnianto Joyonegoro ${ }^{1}$ \\ ${ }^{1}$ Electrical Engineering, Electrical Engineering Department, Universitas Indonesia, Depok, Indonesia. \\ ${ }^{2}$ Tropical Renewable Centre, Faculty of Engineering, Universitas Indonesia, Depok, Indonesia.
}

\begin{abstract}
Electricity that produced by renewable energy sources are countinously increased, but some place in Indonesia have not utilize the renewable sources maximally, for instance Kolorai, South Morotai. Based on data from NASA, solar radiation in kolorai is around $5,99 \mathrm{kWh} / \mathrm{m}^{2} /$ day, so solar power plant is one of solution to solve electricity needs in remote area like Kolorai. Futhermore, in solar power plant project, determining the load profile and designing the stand alone PV with simulation is important to make a great system. So the optimal methods are needed to build those system, the methods that have higher energy output, less excess energy, dan have a low Net Present Cost. In this paper, Australian/New Zealand standart and manual calculation are used to create an economical design. The result of the HOMER simulation shows that using Australian/New Zealand standart have a suitable result with excess electricity value is $8,56 \%$ and Net Present Cost is 1.439.160.000 rupiah.
\end{abstract}

\section{Introduction}

Indonesia is an archipelago country that has various islands in each province. However, mostly areas in the archipelago areas are notelectrified yet especially in eastern Indonesia. Eastern Indonesia are not electrified because to connect its area to grid it will spend to much cost and get many trouble to maintenance it. Based on data, Electrification average ratio in Indonesia is still $93,08 \%$, sulawesi and aceh is $70 \%$, Nusa Tenggara Timur $58,99 \%$, and Kepulauan Maluku and Papua are the lowest with 48,91\%. [1].

One of the renewable energy resources that have the biggest potential in Indonesia is solar energy. Solar energy in Indonesia is almost reach $4.8 \mathrm{kWh} / \mathrm{m}^{2}$ [2]. Solar energy are converted to electricity by solar panel. The using solar panel to generate electricity have some advantages, e.g. low maintenance cost, biggest power than another renewable energy, and no pollution in the convertion process. In the other hand, there are some disadvantages in using of solar panel, e.g high capital and instalation cost.

Solar radiation, solar energy potential in some areas, load profile, and condition in instalation areas are needed to design solar energy power plant. One of the factor in designing solar energy power plant at remote area is ensure the amount of energy consumption in that area. In process of designing system, the load growth projection is needed so that the system that already installed can works well and optimal in technical or non-technical variables. This researchs project objective is to design solar panel system, capacity, and the number of battery that will used in remote area with a little wasted energy and low total NPC. In designing this photovoltaic system, is used some energy consumption asumption for several years.

\section{Method}

\subsection{Location of Case Study}

The area is located in the northern Maluku province, Indonesia specificly in the district kolorai. Kolorai is the island located in the north of Maluku, it can be seen in Figure 1. Geographically, Koloray is in the north of the Equator line and has a coordinate point 02'03'19 "North Latitude and 12'12'43 " East Longitude.
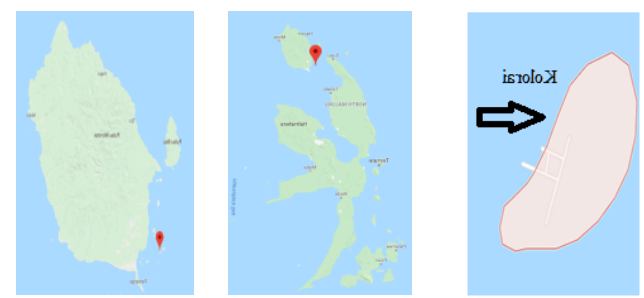

Fig 1.Koloray

\subsection{Irradiation at Koloray}

The longitude is close to equator line, it caused the higher solar radiation. It can be seen in tabel 1. 
Tabel 1. Irradiation at Kolorai[4]

\begin{tabular}{|c|c|}
\hline Bulan & $\begin{array}{c}\text { Radiasi } \\
\text { Matahari(kWh/ } \mathbf{m}^{\mathbf{2}} \mathbf{)}\end{array}$ \\
\hline Januari & 5.26 \\
\hline Februari & 5.91 \\
\hline Maret & 6.43 \\
\hline April & 6.82 \\
\hline Mei & 4.96 \\
\hline Juni & 6.17 \\
\hline Juli & 4.85 \\
\hline Agustus & 6.43 \\
\hline September & 5.78 \\
\hline Oktober & 6.50 \\
\hline November & 6.23 \\
\hline Desember & 5.75 \\
\hline Rata-Rata & 5.99 \\
\hline
\end{tabular}

\subsection{Energy Consumption}

The observation was done to obtain the projection of electrical energy consumption in Kolorai Village. Based on the provisions of the feasibility study organizers, the samples must be taken as much as $2 \%$ of the total population and according to the agreement of the Koloray Village Chief, a survey was conducted on 66 Household Head (respondents) of a total of 105 head of household located in the village.

Tabel 2. Energy Consumption

\begin{tabular}{|c|c|c|c|}
\hline \multicolumn{3}{|c|}{ Beban } & Beban Dalam \\
\hline Jam & $\mathrm{kW}$ & $\%$ & $\mathrm{kWh}$ \\
\hline 0 & 2460 & 2,23 & 3,17 \\
\hline 1 & 2460 & 2,23 & 3,17 \\
\hline 2 & 2460 & 2,23 & 3,17 \\
\hline 3 & 2460 & 2,23 & 3,17 \\
\hline 4 & 2460 & 2,23 & 3,17 \\
\hline 5 & 0 & 0 & 0 \\
\hline 6 & 0 & 0 & 0 \\
\hline 7 & 0 & 0 & 0 \\
\hline 8 & 0 & 0 & 0 \\
\hline 9 & 0 & 0 & 0 \\
\hline 10 & 0 & 0 & 0 \\
\hline 11 & 0 & 0 & 0 \\
\hline 12 & 0 & 0 & 0 \\
\hline 13 & 0 & 0 & 0 \\
\hline 14 & 0 & 0 & 0 \\
\hline 15 & 24600 & 22,38 & 31,79 \\
\hline 16 & 0 & 0 & 0 \\
\hline 17 & 0 & 0 & 0 \\
\hline 18 & 24600 & 22,38 & 31,79 \\
\hline 19 & 27880 & 25,37 & 36,02 \\
\hline 20 & 8200 & 7,46 & 10,59 \\
\hline 21 & 4920 & 4,47 & 6,35 \\
\hline 22 & 4920 & 4,47 & 6,35 \\
\hline 23 & 2460 & 2,23 & 3,17 \\
\hline Total & 109880 & 100 & 142 \\
\hline
\end{tabular}

\subsection{Method of Calculating the Design of Solar Powered Systems}

The theoretical base for modelling PV systems can be found in references [5-10].

\subsubsection{Australia/New Zealand Standard[11]}

\subsubsection{PV sizing and selection}

1. Design Load Energy $\left(E_{T o t}\right)$

$$
\begin{gathered}
E_{t o t}=E_{d c}+\frac{E_{a c}}{\mu I n v} \\
=0+\frac{142 \mathrm{kWh}}{0.95}=149,474 \mathrm{kWh}
\end{gathered}
$$

Etot $=$ Energy Total

$\mathrm{Edc}=$ Energy DC

$\mathrm{Eac}=$ Energy AC

$\mu \mathrm{Inv}=$ Efficiency inverter

2. DesignLoad Ah

$$
\begin{aligned}
& \frac{E_{t o t}}{V_{d c}} \\
= & \frac{149,474 k W h}{48 \mathrm{~V}}=3,114 \mathrm{kAh}
\end{aligned}
$$

Etot $=$ Energy Total

$\mathrm{Vdc}=\mathrm{DC}$ Voltage

3. OutputArray

$$
\begin{aligned}
& \frac{\text { DesignLoad Ah }}{\mu \text { Batt }} \\
& =\frac{3,114 k A h}{0.95 \%}=3,277 k A h
\end{aligned}
$$

Design Load Ah= Load Ah

$\mu$ Batt $=$ Efficiency Battery

4. Daily Charge Output per Module

$(1-$ Pabric Tolerance $) x I_{m p} x f_{\text {dirt }} x H_{\text {tilt }}(4)$

$=(1-0.05) x 6,48 x 0.95 \times 5,99=35,658 \mathrm{Ah}$

Imp=Maximum Power Current(from PV module)

5. Number of Parallel Strings Required $\left(\mathrm{N}_{\mathrm{p}}\right)$

$$
\begin{array}{r}
N_{P}=\frac{\text { RequiredArrayoutputx } f_{o}}{\text { DailyChargeoutputperModule }}(5) \\
=\frac{3,277 \text { Ahx 1,3 }}{35,658 \mathrm{Ah}}=119,5=120 \text { Module }
\end{array}
$$

$\mathrm{Fo}=$ Oversupply co-effcient

6. Number of Series Modules per Strings $\left(\mathrm{N}_{\mathrm{s}}\right)$

$$
\begin{aligned}
N s & =\frac{V_{d c}}{V_{O C}} \\
=\frac{48 \mathrm{~V}}{54,7 \mathrm{~V}}=0,88 & =1 \mathrm{Pcs}
\end{aligned}
$$

$\mathrm{Vdc}=\mathrm{Dc}$ Voltage

Voc=Maximum Power Voltage(from PV module)

7. Number of Modules $(\mathrm{N})$

$$
N=N_{p} x N_{s}
$$$$
=120 \times 1=120 \text { Module }
$$

8. Total PV Array Capacity (PPV Array)

$\mathrm{Ppv}$ array $=$ total modul $\mathrm{PV} \mathrm{x}$ power per modul

$\mathrm{pv}$

$$
=120 \times 327 \mathrm{Wp}=39 \mathrm{kWp}
$$




\subsubsection{Battery sizing and selection}

9. Required Battery Capacity

$$
\frac{\text { DesignLoadAhxT aut }}{D o D_{\max } \times \text { temperature correction factor. }}
$$

$$
=\frac{3,114 \times 4}{0.8 \times 0.95}=16,389 \mathrm{kAh}
$$

DoDmax $=$ Depth Of Discharge

Taut= Day of Autonomy

10. Number of string battery(Ns)

$$
\begin{aligned}
& \frac{V_{\text {dcbus }}}{V d c_{\text {batt }}} \\
& =\frac{48 \mathrm{~V}}{12 \mathrm{~V}}=4 \mathrm{Pcs} \\
& \text { Vdcbus }=\text { Bus voltage } \\
& \text { VdcBatt }=\text { Battery Voltage } \\
& \text { 11. Number of paralel battery }(\mathrm{Np}) \\
& \quad \frac{\text { RequiredBatteryCapacity }}{\text { Batterycapacityon } C_{x}} \\
& =\frac{16,389 \mathrm{kAh}}{255 \mathrm{Ah}}=64,27=64 \mathrm{PcS}
\end{aligned}
$$

12. Number of battery

$$
\text { Number of battery }=N s x N p
$$

$=4 \times 64=256$ PCS

\subsubsection{Inverter sizing}

PeakLoadx $f_{o}$

$=36 \times 2=72 \mathrm{~kW}$

$\mathrm{Fo}=$ Oversupply co-effcient

\subsubsection{Manual calculations[12]}

This manual calculation has been done by morteza khatami for Consumer Housing in Mashhad-Iran. Energy consumption in mashhad-iran is $6,6 \mathrm{Kwh} /$ day so by using this calculation obtained solar panel capacity of $1785 \mathrm{~W}$ and the number of batteries used is 2 pieces.

\subsubsection{PV sizing and selection}

1. Total energy during day of autonomy

$$
\text { Day of Autonomy } \times \text { Load Energy }(
$$

$$
4 \times 142 k W h=568 k W h
$$

2. Total current during day of autonomy

$$
\text { Dayof Autonomy } \times \text { LoadCurrent }
$$

$$
4 \times 645,45 A h=2581,82 k A h
$$

3. Load current without inverter efficiency

$$
\frac{\text { Loadcurrent }}{\text { Wiringefficiency } \times D o D}
$$

$$
=\frac{645,45 \mathrm{Ah}}{(0.9 \times 0.8)}=896,46 \mathrm{Ah}
$$

DoD $=$ Depth of Discharge

4. Final Current

$$
\text { LoadCurrentwithoutinverterefficiency }
$$
inverterefficiency

$$
=\frac{896,46}{0,95}=943,65 \mathrm{Ah}
$$

5. Final energy

$$
\text { Final Current x } 220
$$$$
=943,65 \times 220=207602,34 \mathrm{Wh}
$$

6. Final energy with solar radiation

$$
\begin{aligned}
& \frac{\text { Final Energy }}{\text { Solarradiation }} \\
= & \frac{207602,34}{5,99}=36482,27 \mathrm{Wh}
\end{aligned}
$$

7. Number of Modul

$$
\begin{gathered}
\frac{\text { FinalEnergywithsolarradiation }}{\text { Panel Power }} \\
=\frac{36482,27}{327}=111,6=112 \text { modules }
\end{gathered}
$$

8. Total PV array capacity

Ppv array= total modul PV $\mathrm{x}$ power per modul pv

$$
=112 \times 327=37 \mathrm{kWp}
$$

\subsubsection{Battery sizing and selection}

1. Required Battery Capacity

$$
\begin{aligned}
& \underline{\text { Final Energy } \times \text { Day of Autonomy }} \\
& =\frac{207602,34 \times 4}{48}=11,8 \mathrm{kAh}
\end{aligned}
$$

2. Number of string Battery(Ns)

From equation 10:

$$
=\frac{48 \mathrm{~V}}{12 \mathrm{~V}}=4 \mathrm{PCS}
$$

3. Number of parallel Batteru(Np)

From equation 11:

$$
=\frac{12 k A h}{255}=46 \mathrm{Pcs}
$$

4. Number of Battery

From equation 12:

$=4 \times 46=185$ PCS

\subsubsection{Inverter sizing}

Using equation 13

$=36 \times 2=72 \mathrm{~kW}$ 


\section{Result and analysis}

\subsection{Calculation analysis}

The calculation result that have been done in the previous chapter, there will be some analysis in accordance with the calculation parameters of each method. The following data results calculation from both methods.

Tabel 3.Comparison of Australian / New Zealand Standard Calculation Result and Manual Calculation

\begin{tabular}{|l|l|l|l|}
\hline NO & Parameter & $\begin{array}{l}\text { Australia/ } \\
\text { New Zealand } \\
\text { Standar }\end{array}$ & $\begin{array}{l}\text { Manual } \\
\text { Calculation }\end{array}$ \\
\hline 1 & Total Energy load & $149.474 \mathrm{Wh}$ & $142.000 \mathrm{Wh}$ \\
\hline 2 & Power PV/Modul & $327 \mathrm{Wp}$ & $327 \mathrm{WP}$ \\
\hline 3 & $\begin{array}{l}\text { Number of PV } \\
\text { Modules }\end{array}$ & 120 Modul & 112 Modul \\
\hline 4 & $\begin{array}{l}\text { Amount of } \\
\text { Battery }\end{array}$ & $256 \mathrm{Pcs}$ & 185 Pcs \\
\hline 5 & Inverter Capacity & $72 \mathrm{~kW}$ & $72 \mathrm{~kW}$ \\
\hline
\end{tabular}

In calculation methods using Australia/New Zealand standard, there are several parameters to calculate the amount of energy. Parameters used in this calculation is inverter eficiency and DC loads. However, in the load calculation, there is no DC load parameters so, it considered as zero. The parameters that calculated need to considered because it is very important for load total that used in kolorai. Its because of Australia/New Zealand standard consider an efficiency from an inverter to supplies load, so the value of Australia/New Zealand standard is greater than manual calculation of Morteza Khatami.

In the calculation of Australia/New Zealand standard, to consider the quantity of PV moduls that will used, spesification of PV moduls should be known first. Spesifications that needed from PV moduls are fabrication tolerance range, dust factor, short circuit current, and maximum voltage. In fabrication tolerance range, the higher its values, PV moduls that used will be higher too. In consequence, calculation of tolerance value that used can be changed as long as its still in the reasonable range.

While in manual calculation in knowing the number of PV modules that will be used in influenced by several factors, such as DOD (Depth Of Dischare), cable efficiency and also dust factor. Therefore the specification of the PV module to be used will not affect the number of $\mathrm{PV}$ modules that will be used in this manual calculation. So the number of PV modules used in manual calculations is much smaller than the Australian / New Zealand Standard. From each calculation method, the number of PV modules used will be directly proportional to the total load used and to the total energy produced by PV.

From the calculation, each method assumes that Day of Autonomy are four days, which means the battery is capable of backing up the load during cloudy or rainy
conditions.Eventhough the power generated from the PV will be small, the battery will be used continuously during Day of Autonomy without charge from PV. Battery usage needs to be restricted to $80 \%$ in order to keep the duration of battery lifetime.

In Australia / New Zealand Standard there are several parameters that determine the amount of battery that will be use. The parameters are the amount of daily flow, day of autonomy, DoD, and also temperature correction factor. While on manual calculations, the parameters that determine the amount of battery used are Day of Autonomy and the amount of load during Day of Autonomy. This is what causes the Australian / New Zealand Standard use the amount of batteries more than the amount from manual calculation

\subsection{Selection Analysis Using Calculation Method In accordance with Economical and Technical}

In the calculations using the Australian / New Zealand Standard and manual calculations,economical and technical factor must be considered in the installation of solar power system, it should be noted because the biggest problem in the use of renewable energy is whether or not a power generating system is used in the next few years. Here is the data from both calculation methods:

Tabel 4.Simulation results from both Calculation Methods by Using Homer Software

\begin{tabular}{|l|c|c|c|}
\hline \multicolumn{1}{|c|}{$\begin{array}{c}\text { Paramete } \\
\mathbf{r}\end{array}$} & $\begin{array}{c}\text { Australia/ } \\
\text { New } \\
\text { Zealand } \\
\text { Standard }\end{array}$ & $\begin{array}{c}\text { Homer } \\
\text { Optimizer }\end{array}$ & $\begin{array}{c}\text { Manual } \\
\text { Calculatio } \\
\mathbf{n}\end{array}$ \\
\hline $\begin{array}{l}\text { PV } \\
\text { Capacity }\end{array}$ & $39 \mathrm{kWp}$ & $37 \mathrm{kWp}$ & $37 \mathrm{kWp}$ \\
\hline $\begin{array}{l}\text { Amount } \\
\text { of } \\
\text { Battery }\end{array}$ & $256 \mathrm{Pcs}$ & $376 \mathrm{Pcs}$ & $185 \mathrm{Pcs}$ \\
\hline $\begin{array}{l}\text { Excess } \\
\text { Electricity }\end{array}$ & $8,56 \%$ & $3,87 \%$ & - \\
\hline $\begin{array}{l}\text { NPC } \\
\text { Total } \\
\text { (Billion) }\end{array}$ & $\mathrm{Rp} 1,4$ & $\mathrm{Rp} 1,5$ & $\mathrm{Rp} 1,2$ \\
\hline
\end{tabular}

In Standard Australia / New Zealand the value of the excess electricity generated is $8.56 \%$ while in manual calculation, the excess electricity can not be calculatedbecause the manual calculation can not be simulated using homer due to error capacity shortage when compiling. However, the value of excess electricity by using homer optimizer is $3.87 \%$, so the difference of excess electricity valueby using Australian / New Zealand standard withhomer optimizer is $4.69 \%$. The big difference in the excess electricity is due to the PV capacity used in the Australian / New Zealand Standard is greater than the homer optimizer.

In the Australian / New Zealand Standard the total NPC value is Rp1,4 billionwhile with using homer optimizer the total NPC value is Rp1,5 billion. However, by using manual calculation obtain NPC fee of Rp1,2 billion. The difference of NPC value is due to the number 
of batteries from manual calculationis less than the number of batteries by using the Australian / New Zealand Standard. However, the number of batteries from manual calculations can not be used to supply the load that has been determined if the PV capacity used is $37 \mathrm{~kW}$.

From the explanation, using the Australian / New Zealand Standard method is better than the manual calculation, although the value of Total NPC is greater than manual calculation but the excess electricity generated by the system can be obtained rather than using manual calculation. In the installation of solar power systems the value of excess eletricity obtained is at least less than $10 \%$, so the value of excess eletricity produced by the Australian / New Zealand Standard is technically appropriate. While the value of Total NPC in the results should be lower value, so the Australian / New Zealand Standard has met both technically and economically with a small excess electricity value and a low total NPC.

\subsection{Analysis Effect of Day of Autonomy}

In stand-alone PV, day of autonomyhashigh influencetoother parameters. This is because no power plant other than PV is used either to charge the battery or to supply the load, so Day of Autonomy needs to be determined first.It can be seen from fig 2 .

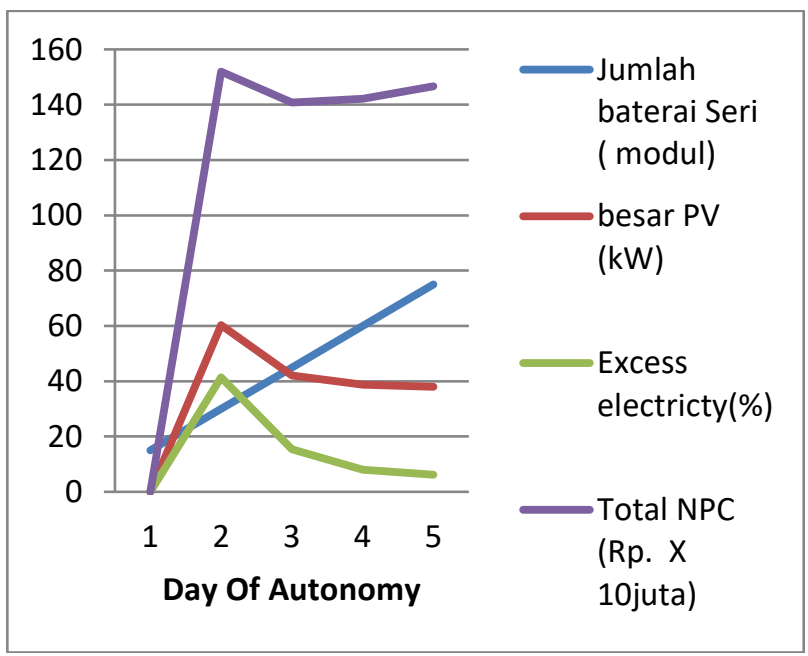

Fig 2 Graph of Day of Autonomy Effect on Number of Batteries, PV capacity, Excess electricity and Total NPC

From figure 2 can be seen the effect of the duration of Day of Autonomy which is determined against the four parameters. The relationship between Autonomous Day with the battery is directly proportional, where the longer Autonomy Day is determined then the capacity of the battery to be used is greater. The more number of batteries used then the need for electrical energy by the load can still be served during Autonomy Day. It aims to keep the system running by simply utilizing the electrical energy in the battery supply. Can be seen at the time of the determination of 1 day Autonomy Day, only battery parameters have this value because the homer can not be run due to lack of capacity so that although the PV used is larger, it still can not meet the demand of electrical energy by the load, this is in the amount generated from the battery used are not able to supply the load during Autonomy Day.

While the relationship between Day of Autonomy with PV capacity is inversely, this is because the number of batteries used during Day of Autonomy. If the required number of batteries is small then the PV capacity used should be large so the system can run properly, but with an increase in PV capacity used will affect the excess power in the system will be even greater. Vice versa if the number of batteries used a lot then the PV capacity used can be smaller, so the value of excess electricity in the system will be smaller. Thus the specified Autonomous Day also affects the value of excess electricity generated in stand-alone PV systems due to the PV capacity used.

In contrast to Day of Autonomy influence on total NPC, it can be seen from the figure 2 that the total change of NPC initially high at Day of Autonomy which specified is 2 day but when Day of Autonomy which determined 3 day total value of NPC become down, and then rises again when the Day of Autonomy value is specified over 3 days. The change in the total value of this NPC follows the number of batteries used and the capacity ofPV that required in the system during the Day of Autonomy. Although the amount of battery required is directly proportional to Day of Autonomy and the PV Capacity needed is inversely proportional to Day of Autonomy but the cost required for batteries and PV is very much different, where the cost for 1 piece battery Rp2 million while the cost for capacity $1 \mathrm{~kW}$ PV Rp12 million.

\section{Conclusion}

the comparison results of both methods show that Australian design methods are more economical and have relatively low electrical surplus with total npc of 1,4 billion and percentage of excess electricity rate of $8,56 \%$. Day of Autonomy affects several parameters in the calculation of stand alone PV system, such as number of batteries, PV capacity, excess electricity and total NPC.

The Author would like to thank this work was supported and finished by "Hibah Pengabdian Masyarakat (PENGMAS) DRPM UI 2017".

\section{References}

1. Naville, Richacard C. 1995. Solar Energy Conversion. Elsevier. USA.

2. Markvart,Thomas.2000.SolarElectricity.John wileys \& sons, LTD. United Kingdom

3. I. Rahardjo and I. Fitriana, "Analysis of the Potential of Solar Power in Indonesia," Strategy. Provision of List. Nas. In Order to Anticipate Users. PLTU Coal Small Coal, Nuclear Power Plant, and Renewable Energy, P3TKKE, BPPT, January, pp. 43-52, 2005.

4. NASA (2017). " SurfaceMeteorology and Solar Energy", Renewable Energy ResourceWebsite.https://eosweb.larc.nasa.gov/sse/

5. T. Ma, H.Yang, L.Lu, "Solar solar panel system modeling andperformance prediction", Renewable 
and Sustainable Energy Reviews,Vol. 36, August 2014, pp. 304-315.

6. D.T Cotfas, P.A Cotfas, S.Kaplanis, "Methods to determine the dcparameters of solar cells: A critical review", Renewable andSustainable Energy Reviews, Vol. 28, Dec. 2013, pp. 588-596.

7. G.Ciulla, V.L Brano, V.D. Dio, G.Cipriani, “A comparison of different one-diode models for the representation of I-V characteristic of a PVcell", Renewable and Sustainable Energy Reviews, Vol. 32, April 2014,pp. 684-696.

8. IEC 61724, Solar panel system performance monitoring - Guidelines for measurement, data exchange and analysis, 1998-04.

9. N.A Kamarzaman, C.W Tan, "A comprehensive review of maximumpower point tracking algorithms for solar panel systems", Renewableand Sustainable Energy Reviews, Vol. 37, Sept. 2014, pp. 585-598.

10. D. Milosavljevic, Studying of energy efficiency of solar power plants inthe Republic of Serbia and the Republic of Srpska”, PhD thesis, Facultyof Sciences and Mathematics Niš, Serbia, 2013.

11. AS / NZS StandardTM. (2010). AS / NZS 4509.2: 2010 Stand-alone power systems ( Vol 2).

12. Morteza Khatami, Hasem Mortazavi, Mostafa Rajabi Mashhadi, Mahdi Oloomi, "Designing an Off-Grid PV System for a Residential Consumer in Mashhad-Iran" 